\title{
Korelasi Dosis Pemupukan Nitrogen terhadap Produktivitas dan Rendemen Tebu (Saccharum officinarum L.)
}

\section{Correlation of Nitrogen Fertilization dosage on Yield and Sugar Content of Sugarcane (Saccharum officinarum $L$.)}

\section{Fitri Isnaini Magandi dan Purwono*}

Departemen Agronomi dan Hortikultura, Fakultas Pertanian, Institut Pertanian Bogor (Bogor Agricultural University), Jl. Meranti, Kampus IPB Darmaga, Bogor 16680, Indonesia Telp. \& Faks.62-251-8629353 e-mail agrohort@apps.ipb.ac.id

*Penulis Korespondensi : puripb@gmail.com

Disetujui : 01 November 2018 / Published Online 06 Mei 2019

\begin{abstract}
Sugarcane farmers in some places give an additional dose of fertilizer more than local fertilizer recommendations, especially $\mathrm{ZA}$, in order to increase the yield. The objectives of this observation is to analyze the correlation of total $N$ fertilizer on yield and sugar content. Obsevation conducted on 4th Februari 2018 and 5th June 2018 at Kebon Agung Sugar Factory, Malang-East Java. The observation was carried out by calculating productivity and measurement of brix. The recommended $N$ fertilizer is $186 \mathrm{~kg} \mathrm{ha}^{-1}$ and recommended $N$ fertilizer doses from sugar factory is $228 \mathrm{~kg} \mathrm{ha}^{-1}$. Observations showed the $N$ fertilizer doses of farmers in the northern region was $274.8 \mathrm{~kg} \mathrm{ha}^{-1}$ while the southern region used $N$ fertilizer dose of $421.5 \mathrm{~kg}$ $h \mathrm{a}^{-1}$. Correlation analysis showed that $N$ fertilizer was significantly correlated with productivity and did not correlate significantly sugar content. Sugar factory gives sugar yield sharing guarantees that encourage farmers to increase productivity by adding fertilization doses, regardless of the yield of sugarcane.
\end{abstract}

Keywords: fertilizer recommendations, sugar yield ratio, ZA

ABSTRAK

Petani tebu dibeberapa tempat memberi tambahan dosis pemupukan melebihi dosis rekomendasi pemupukan setempat, khususnya ZA, untuk meningkatkan produktivitas dan rendemen tebu. Tujuan kajian ini adalah untuk mengetahui korelasi dosis pemupukan $\mathrm{N}$-total yang diterapkan petani dengan produktivitas dan rendemen. Kegiatan penelitian dilakukan pada 4 Februari 2018 hingga 5 juni 2018 di PG Kebon Agung, Malang-Jawa Timur. Kajian dilakukan dengan menghitung produktivitas dan pengukuran brix. Rekomendasi dosis pupuk N-total yang digunakan yaitu $186 \mathrm{~kg} \mathrm{ha}^{-1}$ dan rekomendasi dosis pupuk N-total dari pabrik gula sebanyak $228 \mathrm{~kg} \mathrm{ha}^{-1}$. Hasil kajian menunjukkan bahwa rata-rata pemupukan $\mathrm{N}$-total petani wilayah utara sebesar $274.8 \mathrm{~kg} \mathrm{ha}^{-1}$ sedangkan wilayah selatan menggunakan dosis pupuk $\mathrm{N}$-total sebesar $421.5 \mathrm{~kg} \mathrm{ha}^{-1}$. Uji korelasi menunjukkan bahwa pupuk $\mathrm{N}$ berkorelasi nyata dengan produktivitas dan tidak berkorelasi nyata dengan rendemen tebu. Jaminan bagi hasil gula yang diterapkan oleh pabrik mendorong petani untuk meningkatkan produktivitas dengan cara penambahan dosis pemupukan tanpa memperhatikan rendemen tebu.

Kata kunci: nisbah hasil gula, rekomendasi pemupukan, ZA 


\section{PENDAHULUAN}

Tebu (Saccharum officinarum L.) merupakan tanaman penghasil gula di Indonesia. Produksi gula di Indonesia pada tahun 2017 mencapai 2.1 juta ton (Ditjenbun, 2018). Gula yang digunakan untuk konsumsi rumah tangga adalah Gula Kristal Putih (GKP) yang pemenuhannya berasal dari produksi gula nasional. Gula untuk kebutuhan industri yaitu Gula Kristal Rafinasi (GKR) yang pemenuhannya didapat dari impor gula dalam bentuk raw sugar. Angka konsumsi gula di Indonesia pada tahun 2017 adalah 2.8 juta ton untuk keperluan konsumsi rumah tangga dan 3 juta ton untuk keperluan industri makanan dan minuman (BPS 2018). Defisit pasokan gula pada tahun tersebut dipenuhi dengan melakukan impor gula dalam bentuk raw sugar sebesar 1 juta ton untuk kebutuhan GKP dan 3.4 juta ton untuk kebutuhan GKR yang berasal dari Thailand, Brazil, dan Australia (Ditjenbun, 2017).

Kondisi perkebunan tebu nasional mengalami berbagai penurunan. Luas lahan tebu terus menurun, hingga pada tahun 2017 sebesar 425617 ha. Rata-rata produktivitas dan rendemen nasional berturut-turut yaitu 67.7 ton $\mathrm{ha}^{-1}$ dan 7.3\% (Ditjenbun, 2018). Angka produktivitas tersebut masih tergolong rendah jika dibandingkan dengan potensi produktivitas tebu. Rata-rata rendemen tebu nasional juga belum mampu memenuhi target rendemen untuk mencapai swasembada gula.

Produktivitas dan rendemen tebu ditentukan oleh sistem budidaya tanaman tebu. Salah satu faktor penting dalam pertumbuhan dan perkembangan tanaman tebu agar dapat tumbuh dengan baik dan dapat menghasilkan nira yang berkualitas adalah ketersediaan unsur hara penting yang dibutuhkan selama proses metabolisme tanaman. Kegiatan budidaya yang dilakukan untuk memenuhi kebutuhan unsur hara tersebut adalah pemupukan. Rosdianingsih (2003) menyatakan bahwa dosis pemupukan dalam budidaya tebu disesuaikan dengan kebutuhan tanaman dan tipologi lahan. Mayoritas petani tebu melakukan pemupukan dengan dosis yang direkomendasikan oleh pabrik gula dan dosis tersebut berasal dari arahan Pusat Penelitian Perkebunan Gula Indonesia (P3GI).

Beberapa petani tebu lebih memilih untuk mengaplikasikan dosis pemupukan melebihi dosis rekomendasi untuk meningkatkan produktivitas. Pupuk yang paling banyak ditambahkan adalah pupuk Nitrogen. Penambahan dosis pemupukan tersebut tidak melalui analisis tanaman maupun tanah terlebih dahulu sehingga dapat berpotensi menurunkan produktivitas maupun rendemen jika tambahan pupuk yang diberikan melebihi batas kemampuan tanah dan tanaman. Menurut Mulyono (2009) pemupukan dengan dosis berlebihan dan tidak seimbang dapat berdampak negatif terhadap tanaman dan menurunkan produktivitas selain itu juga menyebabkan dampak negatif terhadap lingkungan.

Pengkajian perbandingan realisasi pemupukan yang diterapkan petani dengan rekomendasi pemupukan yang berlaku di lokasi setempat diharapkan dapat memberikan gambaran umum keadaan di lapangan terkait budidaya tebu khususnya pemupukan. Selain itu analisis korelasi pemupukan dengan produktivitas dan rendemen dibutuhkan untuk mengetahui akibat dari pemupukan yang diterapkan petani.

Tujuan dari kajian ini adalah mengetahui perbandingan rekomendasi dan realisasi dosis pemupukan di daerah setempat dan korelasi dosis pemupukan $\mathrm{N}$-total terhadap produktivitas dan rendemen tebu.

\section{BAHAN DAN METODE}

penelitian dilakukan sejak bulan Februari 2018 hingga Juni 2018di PG Kebon Agung, Malang Jawa Timur. Parameter pengamatan meliputi dosis pemupukan yang diterapkan petani wilayah utara dan wilayah selatan, produktivitas masing-masing wilayah, dan rendemen masingmasing wilayah. Pengamatan kebun dilakukaan di bina wilayah utara dan bina wilayah selatan dengan masing-masing wilayah terdiri dari 15 kebun pengamatan. Kebun yang dipilih merupakan kebun tadah hujan yang ditanami tebu varietas dengan keprasan lebih dari RCII.

Metode langsung meliputi pengambilan data primer terkait data taksasi produksi, kadar brix dan wawancara petani.

Komponen produksi yang diamati dalam kegiatan taksasi produksi yaitu jumlah juring per ha, panjang juring, jumlah batang per meter, panjang batang, dan bobot per meter batang. Komponen tersebut selanjutnya dihitung menggunakan rumus produktivitas yaitu Jumlah juring $\mathrm{x}$ Panjang juring efektif $\mathrm{x}$ Jumlah batang per meter juring $\mathrm{x}$ panjang batang layak panen $\mathrm{x}$ bobot batang per meter. Taksasi produksi dilakukan dengan memilih 3 juring contoh. Setiap juring diambil 10 meter untuk diukur jumlah batangnya. Setiap hektar lahan akan diambil 10 batang contoh untuk diamati panjang batang, dan bobot per meter batang. Batang tersebut ditebang rata tanah, dipotong bagian pucuk hingga daun +1 . 
Pengukuran kadar brix dilakukan dengan mengambil 10 batang contoh dan diukur kadar brix batang tebu tersebut dengan hand refractometer. Nilai brix yang terbaca selanjutnya digunakan untuk mengukur rendemen menggunakan rumus (Purwono, 2003) $\mathrm{R}=$ $0.0254+0.4746 \mathrm{~B}$.

Petani yang diwawancarai merupakan petani di bina wilayah utara dan bina wilayah selatan. Petani yang diwawancarai sebanyak 15 orang tiap wilayah. Pertanyaan yang diajukan meliputi proses budidaya yang diterapkan, idenitas petani, dan analisis usaha tani.

Metode tidak langsung meliputi pengumpulan data sekunder dan data penunjang melalui kajian pustaka yang ada di pabrik. Data sekunder tersebut diantaranya adalah iklim, tipologi lahan, dan kondisi tanaman.

Data dan informasi yang didapat dianalisis menggunakan perhitungan matematika sederhana berupa rata-rata dan persentase. Pengolahan data menggunakan Uji $\mathrm{t}$ pada taraf 5\% untuk mengetahui perbedaan tiap wilayah. Uji korelasi untuk mengetahui korelasi dosis pemupukan terhadap produktivitas dan rendemen. Data yang telah diolah akan diambil kesimpulan. Data sekunder dan data wawancara akan dianalisis secara deskriptif.

\section{HASIL DAN PEMBAHASAN}

\section{Rekomendasi dan Realisasi Dosis Pemupukan}

Dosis pupuk N-total yang diaplikasikan petani melebihi dosis rekomendasi. Berdasarkan pengalaman petani, produktivitas tebu masih belum maksimal dengan dosis pupuk rekomendasi yang ada. Petani di bina wilayah selatan menambah dosis pemupukan lebih tinggi daripada bina wilayah utara (Tabel 1).

Tabel 1. Rekomendasi dan realisasi dosis pemupukan $\mathrm{N}$-total

\begin{tabular}{lccc}
\hline \multirow{2}{*}{ Lokasi } & \multicolumn{2}{c}{ Rekomendasi $\left(\mathrm{kg} \mathrm{ha}^{-1}\right)$} & \multirow{2}{*}{ Realisasi $\left(\mathrm{ku} \mathrm{ha}^{-1}\right)$} \\
\cline { 2 - 3 } & Pabrik Gula & Umum & \\
\hline Utara & 228 & 186 & 274.8 \\
Selatan & 228 & 186 & 421.5 \\
\hline
\end{tabular}

Sumber : wawancara petani

Petani lebih cenderung menambahkan pupuk $\mathrm{N}$ dibandingkan dengan pupuk $\mathrm{P}$ maupun pupuk K. Rata-rata pemupukan N di wilayah selatan sebesar $421.5 \mathrm{~kg} \mathrm{ha}^{-1}$ lebih tinggi daripada wilayah utara yang memiliki rata-rata pemupukan $\mathrm{N}$ sebesar $274.8 \mathrm{~kg} \mathrm{ha}^{-1}$. Penambahan pupuk N dalam bentuk ZA lebih diminati petani daripada dalam bentuk urea atau NPK.

Pupuk ZA lebih dipilih petani karena memiliki kandungan hara lain yaitu belerang (S) sebesar $24 \%$. Unsur belerang dalam tanaman berperan untuk membentuk beberapa asam amino, sehingga dapat membantu pertumbuhan tebu. Selain itu harga pupuk ZA relatif murah yaitu $\mathrm{Rp}$ $150000.00 \mathrm{ku}^{-1}$ jika dibandingkan dengan pupuk NPK dengan harga Rp $230000.00 \mathrm{ku}^{-1}$. Penelitian Gosnell (1970) menyatakan bahwa penggunaan pupuk ZA meningkatkan produktivitas yang sedikit lebih tinggi dibandingkan dengan pupuk urea, selain itu pupuk ZA juga dapat menekan potensi pembungaan secara lebih baik dibandingkan dengan pupuk urea. Fase generatif tebu tidak diharapkan terjadi karena berpotensi menurunkan kandungan sukrosa. Sukrosa dalam batang tebu akan terurai untuk kebutuhan energi pada proses pembungaan. Namun disisi lain penggunaan pupuk ZA juga menyebabkan kandungan sukrosa lebih rendah dan potensi kerebahan lebih tinggi.

\section{Produktivitas}

Pengamatan produktivitas di wilayah utara dan wilayah selatan menunjukkan bahwa rata-rata produktivitas wilayah selatan nyata lebih tinggi daripada produktivitas wilayah utara (Tabel 2).

Tabel 2. Produktivitas lahan wilayah utara dan wilayah selatan

\begin{tabular}{|c|c|c|}
\hline \multirow{2}{*}{ Komponen Produktivitas } & \multicolumn{2}{|c|}{ Wilayah } \\
\hline & Utara & Selatan \\
\hline Jumlah batang $\left(\mathrm{m}^{-1}\right)$ & 7.45 & 7.31 \\
\hline Tinggi batang (m) & 2.38 & 2.54 \\
\hline Bobot batang (kg) & 0.67 & 0.72 \\
\hline Jumlah juring & 900.00 & 900.00 \\
\hline Panjang juring efektif & 10.00 & 10.00 \\
\hline Produktivitas & $1058.20 \mathrm{a}$ & $1210.90 b$ \\
\hline $\begin{array}{r}\text { Keterangan : Angka yang } \\
\text { dalam satu } \\
\text { berdasarkan } \\
\text { kepercayaar }\end{array}$ & $\begin{array}{l}\text { i oleh huru } \\
\text { tidak be } \\
t \quad \text { de }\end{array}$ & $\begin{array}{l}\text { yang sama } \\
\text { geda nyata } \\
\text { gan taraf }\end{array}$ \\
\hline
\end{tabular}

Produktivitas tebu rata-rata di wilayah utara sebesar $1058.2 \mathrm{ku} \mathrm{ha}{ }^{-1}$ nyata lebih rendah dibandingkan rata-rata produktivitas wilayah selatan yaitu $1210.9 \mathrm{ku} \mathrm{ha}^{-1}$. Tebu diwilayah selatan memiliki rata-rata panjang batang dan bobot batang per meter yang lebih tinggi dibandingkan wilayah utara. Hal tersebut diduga karena rata-rata pemupukan $\mathrm{N}$ di wilayah selatan lebih tinggi daripada wilayah utara dan perbedaan jenis tanah dikedua wilayah.

\section{Rendemen}

Rendemen merupakan parameter untuk mengetahui banyaknya gula yang dihasilkan tiap kuintal tebu yang dinyatakan dengan satuan persen. Rata-rata rendemen diwilayah utara yaitu 
5.56 dan wilayah selatan yaitu 5.46. Berdasarkan uji statistik rata-rata rendemen diwilayah utara tidak berbeda nyata dengan wilayah selatan (Tabel $3)$.

Tabel 3. Rerata brix dan rendemen diawal musim giling

\begin{tabular}{lccccc}
\hline \multirow{2}{*}{ Wilayahah } & \multicolumn{4}{c}{ Brix (\%) } & \multirow{2}{*}{ Rendemen (\%) } \\
\cline { 2 - 5 } & Atas & Tengah Bawah Rerata & \\
\hline Utara & 15.43 & 17.38 & 18.37 & 17.06 & $5.56 \mathrm{a}$ \\
Selatan & 15.68 & 17.03 & 17.88 & 16.86 & $5.46 \mathrm{a}$ \\
\hline Sumber & $\begin{array}{l}\text { angka yang disertai huruf yang sama tidak } \\
\text { berbeda nyata menurut uji-t } \\
\text { taraf kepercayaan } 95 \%\end{array}$ & &
\end{tabular}

Rata-rata rendemen pada Tabel 3 menunjukkan keadaan umum rendemen diawal musim giling (awal musim kemarau/Mei). Rendemen tebu diawal musim giling masih tergolong rendah karena fase kemasakan (pengisian sukrosa di batang) maksimal terjadi pada musim kemarau. Varietas tebu yang banyak ditanam petani merupakan varietas BL, varietas masak akhir, sehingga diawal musim giling varietas tersebut memiliki rendemen yang masih rendah.

\section{Korelasi Pemupukan}

Hasil pengkorelasian pemupukan $\mathrm{N}$ dengan produktivitas di wilayah selatan menunjukkan bahwa pupuk $\mathrm{N}$ berkorelasi nyata positif terhadap produktifitas dengan koefisien korelasi sebesar 0.592 (Tabel 4).

Tabel 4. Korelasi pemupukan terhadap produktivitas

\begin{tabular}{lcr}
\hline Wilayah & Produktivitas & \multicolumn{1}{c}{ Rendemen } \\
\hline Utara & $0.317^{\text {tn }}$ & $0.020^{\text {th }}$ \\
Selatan & $0.592^{*}$ & $-0.037^{*}$ \\
\hline
\end{tabular}

Keterangan : $*=$ berkorelasi nyata pada taraf kepercayaan $95 \%$, tn = berkorelasi tidak nyata pada taraf kepercayaan $95 \%$

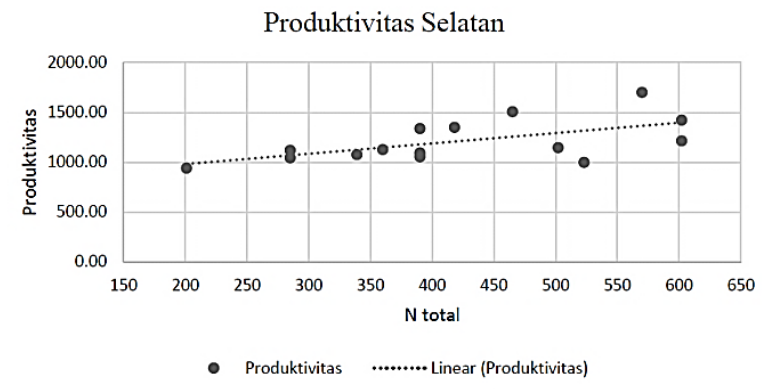

Produktivitas $=774+1.04 \mathrm{~N}$ total

Gambar 1. Grafik regresi N-total dengan produktivitas wilayah selatan

Hasil penelitian Sunaryo (2006) menyatakan bahwa unsur $\mathrm{N}$ berpengaruh nyata terhadap pertumbuhan dan hasil tebu. Unsur $\mathrm{N}$ dapat meningkatkan Leaf Area Indeks (LAI) dan juga meningkatkan jumlah batang dan panjang batang. (Mastur dan Syakir, 2015). Hal yang sama juga dikemukakan oleh Bamber (1984), Muchow et al. (1996), Lofton et al. (2012), dan Saleem et al. (2012) bahwa pemupukan N berpengaruh nyata pada peningkatan panjang batang dan produktivitas tebu. Unsur hara $\mathrm{N}$ dapat meningkatkan aktivitas enzim phosphoenol pyruvate carboxylase (PEPcase) (Hadisaputro et al., 2008). Enzim PEPcase merupakan enzim yang berperan aktif dalam fiksasi karbon tanaman C4. dan meningkatkan efisiensi radiasi surya sehingga dapat meningkatkan proses fotosintesis (Pembengo et al., 2012).

Rata - rata rendemen wilayah utara dan wilayah selatan tidak berbeda nyata yaitu masing - masing sebesar $5.56 \%$ dan $5.46 \%$. Rendemen tersebut merupakan rendemen hasil hitung berdasarkan brix lapangan dan tergolong relatif rendah. Varietas BL merupakan varietas masak tengah akhir sehingga pada awal musim giling (Mei) rendemen tebu varietas tersebut masih rendah.

Hasil pengkorelasian pemupukan dengan rendemen menunjukkan bahwa pemupukan $\mathrm{N}$ di wilayah utara positif namun tidak nyata. Penelitian Muchow et al. (1996) menyatakan bahwa pupuk $\mathrm{N}$ lebih besar pengaruhnya terhadap peningkatan biomassa batang dibandingkan dengan peningkatan kadar sukrosa batang tebu. Pupuk N diwilayah selatan juga tidak berkorelasi nyata dengan rendemen, tetapi angka korelasinya sudah mengarah pada penurunan rendemen. Unsur $\mathrm{N}$ dapat membantu meningkatkan total hasil gula yang merupakan perkalian dari produktivitas dan rendemen tebu (Fortes et al., 2013). Penelitian Wijaya et al. (2016) menyatakan bahwa jumlah pemupukan $\mathrm{N}$ untuk mendapatkan kadar sukrosa yang optimum adalah $315 \mathrm{~kg} \mathrm{ha}^{-1}$, sedangkan realisasi pemupukan $\mathrm{N}$ diwilayah selatan mencapai $426 \mathrm{~kg} \mathrm{ha}$. Pemupukan $\mathrm{N}$ berlebih dapat menurunkan kadar sukrosa karena terurai untuk pembentukan energi yang dibutuhkan untuk mengubah $\mathrm{N}$ mineral menjadi $\mathrm{N}$ organik (Wijaya et al., 2016)

Perbedaan hasil korelasi wilayah utara dengan wilayah selatan diduga karena pempukan $\mathrm{N}$-total di wilayah selatan lebih tinggi daripada wilayah utara. Selain itu perbedaan tesebut juga diduga karena perbedaan kesuburan tanah dan status hara dalam tanah. Keberagaman kondisi lingkungan tumbuh tanaman memungkinkan adanya rekomendasi pemupukan yang berbeda di wilayah yang berbeda. Maka dari itu analisis tanah di masing-masing wilayah dibutuhkan untuk mendapatkan rekomendasi dosis pemupukan yang tepat 


\section{Analisis Usaha Tani}

Penambahan dosis pupuk anornagik sering dipandang sebagai suatu kegiatan yang negatif terkait dengan dampak yang ditimbulkan terhadap keberlanjutan lahan dan lingkungan, tetapi disisi lain penambahan dosis pemupukan dapat meningkatan produktivitas tebu sehingga pendapatan petani juga bertambah. Tabel 5 merupakan gambaran umum perbandingan analisis usaha tani antara petani wilayah utara yang menggunakan dosis rekomendasi dengan petani yang menggunakan dosis pemupukan melebihi dosis rekomendasi. Peningkatan pendapatan petani wilayah utara yang menggunakan dosis pemupukan melebihi rekomendasi mencapai $15.4 \%$.

Tabel 5. Analisis usaha tani wilayah utara

\begin{tabular}{|c|c|c|}
\hline Uraian & $\begin{array}{l}\text { Dosis Sesuai } \\
\text { Rekomendasi }\end{array}$ & $\begin{array}{l}\text { Dosis Melebihi } \\
\text { Rekomendasi }\end{array}$ \\
\hline Produktivitas (ku.ha $^{-1}$ ) & 985.9 & 1056.7 \\
\hline \multicolumn{3}{|l|}{ Pengeluaran (Rp) } \\
\hline 1. Sewa lahan & 13000000 & 13000000 \\
\hline 2. Pupuk & 1820000 & 2650000 \\
\hline \multicolumn{3}{|l|}{ 3. Tenaga Kerja } \\
\hline Pemeliharaan & 10990000 & 10990000 \\
\hline Tebang angkut & 9859000 & 10567000 \\
\hline 4. Potongan KUD & 1242234 & 1331442 \\
\hline 5. Potongan PG & 388050 & 415920 \\
\hline Total (A) & 37299284 & 38954262 \\
\hline \multicolumn{3}{|l|}{ Pengeluaran (Rp) } \\
\hline $\begin{array}{l}\text { 1. Bagi hasil gula } \\
(4.8 \mathrm{~kg} / \mathrm{ku} \text { tebu; } \\
\text { harga gula Rp } \\
9700)\end{array}$ & 45903310 & 49200340 \\
\hline $\begin{array}{l}\text { 2. Tetes tebu (Rp } \\
\text { 3900/ku tebu) }\end{array}$ & 3845010 & 4212130 \\
\hline Total (B) & 49748320 & 53321470 \\
\hline Keuntungan (B-A) & 12449230 & 14367208 \\
\hline
\end{tabular}

Berbeda dengan petani di wilayah utara. Peningkatan produktivitas akibat penambahan pupuk $\mathrm{N}$ di wilayah selatan lebih signifikan dibandingkan di wilayah utara, sehingga petani di wilayah selatan dengan penambahan pupuk $\mathrm{N}$ dengan jumlah yang sama mendapatkan kenaikan pendapatan mencapai $34.7 \%$ (Tabel 6).

Terbukti bahwa petani yang menerapkan dosis pemupukan N-total melebihi dosis rekomendasi mendapatkan pendapatan yag lebih tinggi. Hal tersebut disebabkan karena peningkatan produktivitas.

Penyebab lainnya yaitu pabrik menerapkan sistem jaminan hasil gula kepada petani. Jika produktivitas lahan tebu petani semakin tinggi, maka semakin tinggi pula hasil gua yang didapatkan. Hal tersebut mendorong petani untuk mengejar produktivitas setinggi mungkin dengan cara menambahkan dosis pemupukan, tanpa memperhatikan rendemen.

Tabel 6. Analisis usaha tani wilayah selatan

\begin{tabular}{|c|c|c|}
\hline Uraian & $\begin{array}{l}\text { Dosis Sesuai } \\
\text { Rekomendasi }\end{array}$ & $\begin{array}{c}\text { Dosis Melebihi } \\
\text { Rekomendasi }\end{array}$ \\
\hline Produktivitas $\left(\mathrm{ku}^{-h^{-1}}{ }^{-1}\right)$ & 967.4 & 1070.4 \\
\hline \multicolumn{3}{|l|}{ Pengeluaran (Rp) } \\
\hline 1. Sewa lahan & 15000000 & 15000000 \\
\hline 2. Pupuk & 1820000 & 2650000 \\
\hline \multicolumn{3}{|l|}{ 3. Tenaga Kerja } \\
\hline Pemeliharaan & 11990000 & 11990000 \\
\hline Tebang angkut & 9674000 & 10703000 \\
\hline 4. Potongan KUD & 1121924 & 1348704 \\
\hline 5. Potongan PG & 380767 & 425308 \\
\hline Total (A) & 39986691 & 42114013 \\
\hline \multicolumn{3}{|l|}{ Pengeluaran (Rp) } \\
\hline $\begin{array}{l}\text { 1. Bagi hasil gula } \\
\text { (4.8 kg/ku tebu; } \\
\text { harga gula Rp } \\
\text { 9700) }\end{array}$ & 45041950 & 49837630 \\
\hline $\begin{array}{l}\text { 2. Tetes tebu (Rp } \\
\text { 3900/ku tebu) }\end{array}$ & 3772860 & 49837630 \\
\hline Total (B) & 48814810 & 54012384 \\
\hline Keuntungan (B-A) & 8828119 & 11898371 \\
\hline
\end{tabular}

Sumber: wawancara petani.

\section{KESIMPULAN}

Pemupukan $\mathrm{N}$ di wilayah selatan memiliki korelasi nyata positif terhadap produktivitas tebu dengan koefisien korelasi sebesar 0.592 . Pemupukan $\mathrm{N}$ tidak berkorelasi nyata dengan rendemen baik di wilayah utara maupun di wilayah selatan. Pendapatan petani wilayah utara yang mengaplikasikan dosis pemupukan $\mathrm{N}$ melebihi dosis rekomendasi pupuk bersubsidi meningkat $15 \%$. Pendapatan petani wilaya selatan yang mengaplikasikan dosis pemupukan $\mathrm{N}$ melebihi dosis rekomendasi pupuk bersubsidi meningkat sebesar $30 \%$.

\section{DAFTAR PUSTAKA}

[BPS] Badan Pusat Statistik. Rata-rata konsumsi per kapita seminggu beberapa macam bahan makanan penting 2007-2017. 2018. https://www.bps.go.id/statictable/2014/09/08 1950/rata-rata-konsumsi-per-kapita seminggu -beberapa-macam-bahan-makanan-penting2007-2017.html. [4 Agustus 2018].

[Ditjenbun] Direktorat Jenderal Perkebunan. Statistik Perkebunan Tebu 2015-2017. 2017. http://ditjenbun.pertanian.go.id/tinymcpuk/g ambar/file/statistik/2017/Tebu-2015-2017. pdf. [13 November 2017].

[Ditjenbun] Direktorat Jenderal Perkebunan. 2018. Statistik Perkebunan Tebu. Kementerian Pertanian. Jakarta. 
Gosnell, J. M. 1970. A comparison of the effect of urea and sulphate of ammonia on sugarcane. Proceedings of The South African Sugar Technologists' Assosiation. June 1970.

Hadisaputro, S., K. Rochiman, Mirzawan, G. Sukarso, B. Sugiharto. 2008. Peran hara N dan K terhadap enzim PEPcase dalam daun teb keprasan varietas M442-51 dan PS 60. Jurnal Ilmu Dasar. 9:62-71.

Inman-Bamber, N.G. 1984. The effects of nitrogenous fertilizer on sugarcane virieties and varietal differences in third leaf nutrient content. Proc. Of The South African Sugar Technologists' Association. June 1984.

Lofton J., B. Tubana. 2015. Effect of nitrogen rates and application time on sugarcane yield and quality. Journal of Plant Nutrition 38:161176.

Mastur, S., M. Syakir. 2015. Peran dan pengelolaan hara nitrogen pada tanaman tebu untuk peningkatan produktivitas tebu. Perspektif. 14:73-86.
Muchow, R.C., M.J. Roberson, A.W. Wood, B.A. Keating. Effect of nitrogen on time-course of sucrose accumulation in sugarcane. 1996. Field Crops Research. 47:143-153

Pembengo W., Handoko, Suwarto. 2012. Efisiensi penggunaan cahaya matahari oleh tebu pada berbagai tingkat pemupukan nitrogen dan fosfor. J. Agronomi Indonesia. 40(3):211217.

Wijaya, K.A., S. Soeparjono. 2015. Efek suplai nitrogen terhadap kadar gula nira tebu varietas Bululawang. Jurnal Agritrop. 13:109-112. 